\title{
Wiktor SZEWCZAK
}

Toruń

\section{Jak zmierzyć demokrację? Skale pomiaru demokracji politycznej stosowane w politologii porównawczej}

\begin{abstract}
Wstęp
$\mathbf{W}$ ilościowych politologicznych badaniach porównawczych często stosuje się syntetyczne wskaźniki wielowymiarowych zmiennych. Jednym z chyba najbardziej wyrazistych tego przykładów jest używanie tzw. skal bądź indeksów demokracji. Są to narzędzia teoretyczno-metodologiczne, za pomocą których usiłuje się mierzyć poziom demokratyczności systemów politycznych, a następnie przedstawiać go w postaci odpowiadającej mu wartości liczbowej. Tym samym niejednorodna, wielowymiarowa i bardzo złożona charakterystyka systemu politycznego zostaje sprowadzona do najprostszej możliwej postaci.

Tak daleko idące uproszczenie bywa niekiedy uzasadnione specyficznymi celami badawczymi. Jest ono jednak, z metodologicznego punktu widzenia, zabiegiem wymagającym wyjątkowej ostrożności oraz umocowania teoretycznego. Proces tworzenia jednowymiarowej skali tak złożonego zjawiska, jakim jest demokracja, musi być przeprowadzony bardzo rozważnie, opierać się na silnych podstawach teoretycznych i przejrzystych procedurach badawczych. Jest to więc zadanie bardzo trudne i pracochłonne, nie zawsze jego realizacja przynosi satysfakcjonujące wyniki. Mimo tego, podjęte zostało ono przez wielu badaczy, niekiedy z lepszym, a niekiedy z gorszym skutkiem.

W poprzednim numerze czasopisma przedstawione zostały teoretyczne i metodologiczne podstawy tworzenia skal demokracji ${ }^{1}$. Są to skomplikowane kwestie, warto więc wiedzieć jak sobie z nimi radzą badacze podejmujący takie wyzwanie. W tym artykule chciałbym zatem pokrótce scharakteryzować najbardziej rozpowszechnione w anglosaskiej politologii porównawczej skale, a także pokusić się o krótką ich ocenę pod względem adekwatności teoretycznej i metodologicznej poprawności. Tekst skupiać się będzie zatem na kilku celach, składających się na charakterystykę poszczególnych skal. Te cele to przede wszystkim: wskazanie na podstawy teoretyczne oraz założenia metodologiczne prezentowanych skal, wyodrębnienie najbardziej charakterystycznych cech, wreszcie przedstawienie silnych i słabych stron poszczególnych skal. Analizie poddane zostaną te skale, których wpływ na współczesne badania z zakresu politologii porównawczej wydaje się być największy.
\end{abstract}

\section{Analizy Samuela Huntingtona}

Najprostsze skale demokracji odnoszą się wyłącznie do minimalnych warunków demokratyczności systemu politycznego i są pochodną definiowania demokracji w kategoriach

\footnotetext{
${ }^{1}$ W. Szewczak, Jakzmierzyć demokrację? Teoretyczne i metodologiczne podstawy budowy skal demokracji politycznej w politologii porównawczej, ,Przegląd Politologiczny” 2010, nr 4, s. 97-108.
} 
rywalizacyjnych, zaproponowanego przez J. Schumpetera ${ }^{2}$. Podobnie jak owa minimalistyczna definicja demokracji poddana została szerokiej krytyce ${ }^{3}$, tak i czysto proceduralne, odwołujące się do samych tylko cyklicznych i rywalizacyjnych wyborów, koncepcje pomiaru demokratyczności systemów politycznych wydają się dalekie od doskonałości. Dziś nie mamy bowiem wątpliwości, że wybory do ciał przedstawicielskich stanowią wprawdzie warunek konieczny, ale niewystarczający do orzeknięcia o demokratyczności systemu. Niektóre zdobyły jednak duży rozgłos i wpływ na dyskusję nad problemem demokratyzacji.

Na takiej prostej koncepcji pomiaru demokracji oparte są między innymi analizy Samuela Huntingtona, w których poszukiwał on źródeł transformacji demokratycznych zachodzących w XX stuleciu ${ }^{4}$. Utożsamia się w niej demokrację z faktem odbywania się w danym państwie równych, uczciwych i cyklicznych wyborów, w których wyłaniani są najważniejsi decydenci życia zbiorowego ${ }^{5}$. Sam Huntington określa takie definiowanie mianem skromnej koncepcji demokracji ${ }^{6}$. Oparta na takiej koncepcji skala odznacza się jednowymiarowością (demokracja jest traktowana jako zmienna jednowymiarowa) oraz dwustopniowością (skala opiera się na dychotomicznym podziale na reżimy demokratyczne i niedemokratyczne).

Tak skonstruowane narzędzie teoretyczne odznacza się niewątpliwie pewnymi walorami. Uzyskany w wyniku jego zastosowania podział jest ostry i jednoznaczny, daje więc materiał wyrazisty, łatwo poddający się interpretacji i zastosowaniu w analizach ilościowych. Można też spodziewać się wysokiej rzetelności takiej skali, albowiem wskaźnik na jakim jest ona oparta jest względnie jednoznaczny, intuicyjnie zrozumiały i prosty w zastosowaniu (chociaż i tu występują pewne niejasności, np. nieprecyzyjne jest sformułowanie o tym, że wybory mają być równe).

Z punktu widzenia merytorycznej wartości prowadzonych analiz, zastosowanie tak skromnego narzędzia pomiaru jest jednak z kilku względów ryzykowne. Po pierwsze, jeżeli za jedyne kryterium przyjmie się fakt odbywania się cyklicznych, rywalizacyjnych wyborów, to w jednej kategorii znajdą się tak odmienne kraje jak np. Ukraina i USA, Brazylia i Wielka Brytania, RPA i Szwecja itd. Po drugie, taki podział nie uwzględnia w żadnym stopniu modelu wielości modeli demokracji - nie mówi nic o tym czy jest to demokracja konsensualna czy majorytarna, czy dany system jest inkluzyjny czy wykluczający itd. Po trzecie, pomija się w ten sposób wiele nieodzownych aspektów funkcjonowania systemów demokratycznych, mamy tu więc do czynienia z niską zawartością informacyjną skali, graniczącą wręcz z jej teoretyczną nieadekwatnością.

Przydatność zastosowania takiej upraszczającej dychotomicznej i jednowskaźnikowej skali jest uzależniona do obranych celów. Niekiedy może ona dobrze spełnić swoją rolę, szczególnie w analizach o charakterze popularnonaukowym. Jednak w większości przypadków będzie to narzędzie nieadekwatne, którego wady dominują nad ewentualnymi zaletami. Do oceny jakości funkcjonowania demokracji jest ono już całkowicie nieużyteczne.

\footnotetext{
${ }^{2}$ Patrz: J. A. Schumpeter, Kapitalizm, socjalizm, demokracja, Warszawa 2009, s. 336-353.

${ }^{3}$ I. Shapiro, Stan teorii demokracji, Warszawa 2006, s. 78-85; Ch. Mouffe, Paradoks demokracji, Wrocław 2005, s. 98 i n.; A. Gutman, Demokracja, w: Przewodnik po współczesnej filozofii politycznej, red. R. E. Goodin, F. Pettit, Warszawa 2002, s. 531-532.

${ }^{4}$ S. P. Huntington, Trzecia fala demokratyzacji, Warszawa 1995.

5 Ibidem, s. 17.

${ }^{6}$ S. P. Huntington, The Modest Meaning of Democracy, w: Democracy in the Americas: Stopping the Pendulum, red. R. A. Pastor, New York-London 1989.
} 


\section{Freedom House}

Jednym z najbardziej znanych i najczęściej przywoływanych przez badaczy programów pomiaru demokracji jest doroczny raport przygotowywany przez amerykańską organizację pozarządową Freedom House ${ }^{7}$. Prowadzi ona systematyczne monitorowanie wolności w świecie już od lat 50-tych XX wieku. Od 1972 roku oparte są one na metodologii stworzonej przez Raymonda Gastila.

W rzeczywistości Freedom House prowadzi dwojakiego rodzaju pomiar. Efektem pierwszego jest ranking wolności w świecie, natomiast drugiego - wykaz tzw. demokracji wyborczych (electoral democracies).

Pomiar stanu wolności nie odnosi się wprost do demokracji, jednak często jest uznawany za formę pomiaru właśnie niej. Autorzy badania stwierdzają bowiem explicite, że wolność jest dla wszystkich ludzi najlepiej osiagalna w systemach demokracji liberalnej. Badają zatem poziom demokracji, który warunkuje poziom wolności jednostkowej.

W badaniu tym mierzy się demokrację w dwóch podstawowych wymiarach: wymiar politycznych praw oraz wymiar swobód obywatelskich. W procesie oceny badacze odpowiadają na pytania przypisane do poszczególnych wymiarów demokracji (w wymiarze swobód obywatelskich jest to 15 pytań, zaś w wymiarze praw politycznych - 10 pytań plus 2 pytania dyskrecjonalne, odnoszące się do niektórych państw). Odpowiedzi formułowane są w postaci ilościowej (od 0 do 4 punktów), na podstawie bardziej szczegółowych wskaźników przypisanych do każdego pytania. Większa ilość przyznanych punktów oznacza wyższy poziom wolności w danym zakresie.

Pomiar obejmuje następujące charakterystyki systemów politycznych:

I. Wymiar praw politycznych:

a) proces wyborczy - wyłanianie krajowych władz ustawodawczych i innych władz państwowych $\mathrm{w}$ drodze uczciwych i wolnych wyborów oraz charakter systemu wyborczego i prawa wyborczego;

b) polityczny pluralizm i uczestnictwo - swoboda organizowania się, rola opozycji, wolność wyborów dokonywanych w sferze polityki od nacisków ze strony wpływowych grup, prawa wyborcze i swoboda uczestnictwa politycznego grup mniejszościowych;

c) sposób funkcjonowania władzy państwowej - wpływ władz pochodzących z wyboru na politykę państwa, poziom korupcji, otwartość i przejrzystość władzy oraz jej odpowiedzialność wertykalna w okresie między wyborami;

II. Wymiar swobód obywatelskich:

a) wolność wyznania i wypowiedzi - wolność i niezależność mediów, wolność praktyk religijnych, wolność akademicka, otwarta i wolna wymiana poglądów w sferze prywatnej;

b) prawa zrzeszeniowe i organizacyjne - wolność zrzeszania się i demonstracji, otwarta publiczna wymiana poglądów, działalność organizacji pozarządowych, rola związków zawodowych i negocjacji zbiorowych;

\footnotetext{
${ }^{7}$ Historia, podstawy teoretyczne oraz metodologia badania Freedom House zostały przedstawione na stronie internetowej organizacji (http://www.freedomhouse.org i odpowiednie podstrony [5.01.2010]). Patrz też: R. D. Gastil, The Comparative Survey of Freedom: Experiences and Suggestions, „Studies in Comparative International Development" 1990, vol. 25, Issue 1.
} 
c) rządy prawa - niezależność sądownictwa, kontrola cywilna służb mundurowych, pokój wewnątrz państwa, ochrona przed terrorem politycznym, równość traktowania różnych segmentów populacji kraju;

d) autonomia osobista i prawa indywidualne - swoboda podróży, wyboru miejsca zamieszkania, zatrudnienia i pobierania nauki, prawo do własności prywatnej oraz swoboda działalności gospodarczej, wolności socjalne, równość szans w gospodarce i brak wyzysku ekonomicznego.

Łącznie na indeks składa się 27 pytań (w tym dwa pytania dyskrecjonalne) oraz 146 przypisanych im wskaźników. Jest to więc indeks rozbudowany i szczegółowy, traktujący badaną problematykę bardzo szeroko.

Suma punktów w każdym z ocenianych dwóch wymiarów zostaje proporcjonalnie przeliczona na ocenę poziomu wolności w danym wymiarze. Ostatecznym wskaźnikiem wolności/demokracji jest średnia ocen z obu wymiarów.

Oprócz tego Freedom House prowadzi też analizy odwołujące się bezpośrednio do kategorii demokracji, tworząc wykaz tzw. demokracji wyborczych na świecie. Są to państwa bądź terytoria zależne, które spełniają przynajmniej w minimalnym stopniu standardy demokracji:

1) rywalizacyjny, przynajmniej dwupartyjny system polityczny;

2) powszechne prawo wyborcze;

3) regularne wybory, odbywające się na zasadzie tajności głosowania, przy zachowaniu bezpieczeństwa głosujących oraz bez oszustw wyborczych na masową skalę;

4) dostęp wszystkich głównych sił politycznych do mediów oraz możliwości prowadzenia otwartej kampanii politycznej.

Do grona demokracji wyborczych z pomocą państwa kwalifikuje się na podstawie odpowiedzi na część pytań z ankiety ogólnej. Są to pytania odnoszące się do procesu wyborczego, a więc części A w wymiarze praw politycznych:

- Czy szef rządu lub inne najwyższe władze państwowe są wyłaniane w drodze wolnych i uczciwych wyborów?

- Czy członkowie krajowych władz ustawodawczych są wyłaniani w drodze wolnych i uczciwych wyborów?

- Czy istnieje wolna i otwarta wymiana poglądów w sferze prywatnej?

Punktacja jest tu podobna jak w przypadku rankingu wolności w świecie - w każdym z pytań przydziela się od 0 do 4 punktów. Kraj jest uznany za demokrację wyborczą wówczas gdy uzyskuje łącznie przynajmniej 7 punktów. Ponadto od ubiegłorocznej edycji raportu wprowadzone zostało dodatkowe kryterium: kraj musi uzyskać przynajmniej 20 punktów (na 40 możliwych) w całym wymiarze praw politycznych.

Opracowania Freedom House są powszechnie znanym i często używanym źródłem danych w badaniach porównawczych i historyczno-porównawczych nad demokracją ${ }^{8}$. Ich podstawowe zalety to szeroki zasięg geograficzny i systematyczność prowadzonych analiz. Przygotowywane są one rokrocznie w oparciu o niemal niezmienioną metodologię od po-

${ }^{8}$ Przykłady takiego zastosowania znajdują się m.in. w: Ch. Tilly, Demokracja, Warszawa 2008; R. Inglehart, Ch. Welzel, Modernization, cultural change, and democracy: the human development sequence, New York 2005, s. 149-209; R. J. Barro, Determinants of Democracy, „Journal of Political Economy” 1999, vol. 107, Issue 6, Part 2, s. 158-182; J. O'Loughlin, Global Democratization: Measuring and Explaining the Diffusion of Democracy, w: Spaces of Democracy. Geographical Perspectives on Citizenship, Participation and Representation, red. C. Barnett, M. Low, London-Thousand Oaks-New Delhi 2004, s. 29-41 oraz inni. Wielu autorów twierdzi, że jest to wskaźnik używany najczęściej, zarówno w analizach naukowych, jak i w tekstach publicystycznych, ekspertyzach rządowych itp. 
czątku lat 70-tych XX wieku i obejmują wszystkie większe państwa i terytoria zależne świata. Daje to możliwość prowadzenia szeroko zakrojonych badań porównawczych, jak również analizowania ciagów czasowych. Nie bez znaczenia jest również łatwa dostępność danych - wszystkie materiały zawierające wyniki analiz oraz opis metodologii są dostępne na stronach internetowych organizacji.

Same indeksy stworzone przez Freedom House są bardzo złożone, traktuje się w nich wolność i demokrację bardzo szeroko. Analizy mają kompleksowy i rozbudowany charakter, możliwy do uzyskania tylko w dużych i dysponujących sporymi zasobami zespołach badawczych. Każdy kraj, oprócz oceny liczbowej, został opatrzony dość obszerną charakterystyką opisową, obejmującą krótki zarys jego uwarunkowań historycznych, opis najważniejszych instytucji politycznych oraz aktualnych wydarzeń mających wpływ na poziom demokracji w danym kraju.

\section{Ocena jakości demokracji w badaniach IDEA}

Inną organizacją zajmującą się oceną poziomu demokratyzacji oraz jakości demokracji jest International Institute for Democracy and Electoral Assistance (IDEA) ${ }^{9}$. Jej podstawowym celem jest wspieranie procesów demokratyzacji i poprawy jakości demokracji, między innymi poprzez jej ocenę w poszczególnych krajach.

Badania prowadzone przez IDEA oparte są na jednolitej metodologii, jednak nie mają one charakteru typowo porównawczego. Ich celem nie jest porównywanie poziomu demokracji w różnych krajach, ale formułowanie obszernej i wyczerpującej oceny demokracji w każdym $\mathrm{z}$ badanych krajów z osobna.

Schemat operacjonalizacyjny sformułowany dla potrzeb badania opiera się na przejściu od podstawowych zasad demokratycznych, poprzez wartości demokratyczne (pośredniczące), do konkretnych pytań badawczych. Uznaje się tu, że demokracja opiera się na dwóch fundamentalnych zasadach: 1) kontroli ludu nad decydentami politycznymi oraz 2) równości politycznej tych, którzy ową kontrolę sprawują. Z tych zasad wyprowadzić można siedem wartości demokratycznych: partycypacja, autoryzacja, reprezentacja, odpowiedzialność, przejrzystość, responsywność oraz solidarność. Z nich z kolei wywodzą się konkretne pytania badawcze. Są one podzielone na cztery tzw. „filary demokracji”:

1. Filar I - Obywatelstwo, prawo $i$ prawa: brak dyskryminacji żadnej z grup pod względem wspólnoty obywatelstwa, rządy prawa i dostęp do wymiaru sprawiedliwości, równe gwarancje praw politycznych i obywatelskich, równe gwarancje praw ekonomicznych i socjalnych.

2. Filar II - Reprezentatywność i odpowiedzialność władz: wolne, uczciwe i znaczące wybory, rola partii politycznych, efektywność i responsywność władz, rola władzy ustawodawczej, cywilna kontrola nad wojskiem i służbami mundurowymi, uczciwość w życiu publicznym.

3. Filar III - Spoleczeństwo obywatelskie i partycypacja ludowa: rola mediów, partycypacja polityczna obywateli, decentralizacja.

\footnotetext{
${ }^{9}$ Metodologię badań nad demokracją IDEA rekonstruuję na podstawie publikacji tej organizacji: D. Beetham, E. Carvalho, T. Landman, S. Weir, Assessing the Quality of Democracy. A Practical Guide, Stockholm 2008 oraz T. Landman, Assessing the Quality of Democracy. An Overview of the International IDEA Framework, Stockholm 2008. Także: D. Beetham, S. Bracking, I. Kearton, N. Vittal, S. Weir, The State of Democracy. Democracy Assessments in Eight Nations Around the World, Kluwer Law International, Hague 2002.
} 
4. Filar IV - Demokracja poza granicami państwa: wpływy zewnętrzne na demokrację w kraju, oddziaływanie polityki zagranicznej kraju na wzmacnianie demokracji na świecie.

Łącznie analizowanych jest 15 zagadnień, poprzez pryzmat 75 pytań szczegółowych.

Pomiar demokracji w badaniach IDEA odznacza się wieloma cechami charakterystycznymi na tle pozostałych skal. Pierwszą i zasadniczą są specyficzne cele, jakie stawiają sobie autorzy badania - jego aspekt poznawczy odsuwa się na drugi plan, zaś podstawowym zadaniem jest wspieranie reform demokratyzacyjnych oraz przyczynianie się do poprawy jakości demokracji w danym kraju. Efektem oceny mają być gotowe projekty działań mających poprawić jakość demokracji, a także wzmocnienie debaty obywatelskiej w danym kraju. Dlatego proces oceny nie odbywa się w zamkniętym gronie specjalistów, ale angażuje szerokie i reprezentatywne kręgi społeczeństwa.

Drugą cechą charakterystyczną badania, jest to, iż jest ono oparte o założenia relatywizmu kulturowego. We wszystkich pozostałych indeksach zakłada się jednolitość, stałość i powszechność kryteriów demokracji. Tu natomiast przyjmuje się, że kryteria wyprowadzane z podstawowych zasad demokratycznych mają jedynie charakter szkieletowy, zaś dokładne ramy oceny są zależne od kontekstu kulturowego i historycznego danego kraju. To sami członkowie społeczeństwa mają wybierać jakie szczegółowe kryteria i standardy oceny uważają za właściwe, zgodne z własnymi odczuciami i sposobem pojmowania demokracji. Są one więc pochodną historii danego kraju, jego kultury czy wartości uznawanych tam za szczególnie ważne.

Do tej pory w ramach prac IDEA ocenie zostało poddanych ponad 20 krajów z różnych kontynentów, m.in.: Australia, Bangladesz, Bośnia i Hercegowina, Salwador, Indie, Irlandia, Włochy, Kenia, Łotwa, Malawi, Mongolia, Nepal, Holandia, Nowa Zelandia, Pakistan, Peru, Filipiny, Korea Południowa, Sri Lanka oraz Wielka Brytania z Irlandią Północną. Rezultaty tych ocen przyjmują najczęściej postać monografii, zawierających również konkretne propozycje działan ${ }^{10}$.

\section{Indeks demokracji przygotowany przez The Economist Intelligence Unit (indeks EIU)}

Kolejną skala jest indeks demokracji przygotowany dla potrzeb brytyjskiego tygodnika "The Economist" przez jego dział badawczy (The Economist Intelligence Unit) ${ }^{11}$. Jest to przykład bardzo szerokiej konceptualizacji demokracji, autorzy przyjęli bowiem jako punkt odniesienia analizy prowadzone przez Freedom House i stwierdzili, iż traktuje się tam demokrację zbyt wąsko. Potrzebne jest, ich zdaniem, silniejsze uwzględnienie zmiennych do-

\footnotetext{
${ }^{10}$ Na przykład: R. Wilford, R. Wilson, K. Claussen, Power to the People? Assessing Democracy in Northern Ireland, New Island Books, Dublin 2007; I. Hughers, P. Clancy, C. Harris, D. Beetham, Power to the People? Assessing Democracy in Ireland, New Island Books, Dublin 2007; D. Ch. Barman, M. G. Rahman, T. Siddiqui, State of Democracy in Bangladesh, Momin Offset Press, Dhaka 2000; S. Dizdarević et al., Democracy Assessment in Bosnia and Herzegovina, Open Society Fund Bosnia and Herzegovina, Sarajevo 2006; How Demorcatic is Latvia. Audit of Democracy, red. J. Rozenvalds, I. Mežaraups, Latvijas Universitāte Akadēmiskais apgāds, Riga 2005 i inne.

${ }^{11}$ L. Kekic, The Economist Intelligence Unit's index of democracy, „The Economist” 2006, nr specjalny: The World in 2007; The Economist Intelligence Unit's Index of Democracy 2008, „The Economist” 2008, nr specjalny: The World in 2009.
} 
tyczących takich wymiarów jak funkcjonowanie władzy czy partycypacja obywatelska. Dlatego w indeksie EIU proponuje się pomiar oparty na pięciu kategoriach:

1) proces wyborczy i pluralizm, będący niezbędnym warunkiem wolnych, uczciwych i rywalizacyjnych wyborów;

2) swobody obywatelskie, czyli ochrona podstawowych praw człowieka, takich jak wolność słowa, wypowiedzi i prasy, wolność wyznania, wolność zrzeszania się oraz prawo do uczciwego procesu;

3) funkcjonowanie władzy - ocena skuteczności i przejrzystości władzy, jej wolności od nacisków zewnętrznych i korupcji, systemu wzajemnej kontroli władz itp.;

4) kultura polityczna - aktywność obywatelska, zachodząca w określonych ramach i oparta o respektowanie reguł demokratycznych;

5) partycypacja - aktywne uczestnictwo obywateli w debacie publicznej, w wyborze przedstawicieli, w działalności partyjnej itp.

Autorzy indeksu dużą rolę przykładają do zmiennych odnoszących się do uwarunkowań kulturowych i świadomościowych, wychodząc z założenia, że demokracja to również zaangażowanie w sferę publiczną szerokich rzesz obywateli, dialog, poszanowanie praw innych oraz aktywna realizacja zasady równości, wzajemnego zaufania czy wspólnotowości. Dlatego $\mathrm{w}$ indeksie zamieszcza się takie, nietypowe dla skal demokracji, zmienne jak: poziom zaufania do władzy i partii politycznych, charakter wyborów do władz lokalnych, gotowość obywateli do brania udziału w demonstracjach, poziom zainteresowania obywateli polityka, odsetek obywateli śledzących codziennie wydarzenia polityczne w mediach, odsetek osób piśmiennych w społeczeństwie czy procentowy udział kobiet zasiadających w parlamencie. Wszystkie one wskazują na wielowymiarowość zastosowanej koncepcji demokracji, tak dalece rozwinięta, że wręcz skutkującą jej amorficznością ${ }^{12}$.

Konstrukcja wskaźnika i jego wielowymiarowość powodują, iż z jego pomocą możliwe jest analizowanie różnic w poziomach demokratyczności między krajami powszechnie uznawanymi za demokratyczne. Przeprowadzone analizy wykazują bowiem istotne różnice w wartości indeksu np. między Szwecją $(9,88)$, USA $(8,22)$, Wielką Brytanią $(8,08)$ i Włochami $(7,73)^{13}$. Na podstawie wartości indeksu można zatem nie tylko odróżniać systemy demokratyczne od niedemokratycznych, ale również oceniać jakość demokracji w krajach należących do tej pierwszej kategorii.

Należy jednak pamiętać, że konstrukcja wskaźnika nie gwarantuje dokładności dokonanego pomiaru. Jakkolwiek bowiem wartość indeksu demokratyczności jest podawana z dokładnością do dwóch miejsc po przecinku, to wszystkie zmienne stanowiące wskaźniki cząstkowe mają charakter dychotomiczny lub trychotomiczny, a zatem poziom precyzji ich pomiaru jest niski. Autorzy skali postawili sobie za cel uzyskanie przede wszystkim wyższej jej rzetelności i prostoty, godząc się świadomie na pewne uproszczenia i niedokładności.

$\mathrm{Na}$ indeks składa się 60 pytań, pogrupowanych na pięć segmentów, odpowiadających wskazanym wyżej pięciu wymiarom demokracji. Poszczególne odpowiedzi punktowano: 1 (demokratyczność), 0 (niedemokratyczność) lub 0,5 punktu (odpowiedź pośrednia - w przypadku zmiennych trychotomicznych). Punkty za odpowiedzi w każdym z pięciu segmentów są sumowane, a następ-

\footnotetext{
12 Jakkolwiek konceptualizacja demokracji w indeksie EIU jest bardzo szeroka, to nie jest najszerszą z możliwych. Autorzy indeksu wskazują, iż niektóre koncepcje włączają w zakres skal demokracji zmienne dotyczące rozwoju ekonomicznego, rozwoju społecznego itd., sami zaś świadomie tak szerokie rozumienie demokracji odrzucają.

${ }^{13}$ Są to przykładowe wartości wskaźnika z badania z 2006 roku; za: L. Kekic, The Economist Intelligence Unit's index of democracy, op. cit., s. 3.
} 
nie przeliczane proporcjonalnie na skalę od 0 do 10 (przy czym wartość ta jest korygowana w dół jeżeli dane państwo nie spełnia standardów demokracji w podstawowych kwestiach). Ostateczną wartość indeksu ogólnego EIU stanowi średnia z wszystkich pięciu segmentów.

Na podstawie wartości indeksu kraje są klasyfikowane jako:

- pełna demokracja-8-10 pkt,

- niepełna (wadliwa) demokracja - 6-7,9 pkt,

- reżim mieszany (hybrydowy) - 4-5,9 pkt,

- reżim autorytarny - poniżej 4 pkt.

Badanie ma mieć charakter cykliczny, do tej pory odbyło się dwukrotnie (w 2006 i 2008 roku). Za jedną z podstawowych cech odróżniających indeks EIU od pozostałych skal demokracji autorzy uważają przede wszystkim fakt wykorzystania danych z badań świadomości społecznej i opinii publicznej, przede wszystkim ze Światowego Sondażu Wartości, a także z Eurobarometru, badań Instytutu Gallupa, sondaży krajowych i innych. Ciekawostką jest również zastosowanie jako jednego ze wskaźników demokracji charakteru relacji między legislatywą a egzekutywą - system rządów parlamentarno-gabinetowych jest oceniany jako bardziej demokratyczny niż systemy prezydenckie i mieszane.

\section{Skala Bollena}

Niektóre skale przygotowuje się głównie z myślą o ich zastosowaniu w analizach czysto naukowych. Służyć mają one jako wyspecjalizowane narzędzia teoretyczne w politologicznych badaniach porównawczych.

Przykładem może być skala opracowana przez amerykańskiego statystyka i socjologa Kennetha A. Bollena. Punktem wyjścia dla jej autora jest stworzona przezeń definicja demokracji, oparta na określeniu dystrybucji władzy politycznej pomiędzy elitami a nieelitami. Do elit politycznych zalicza on tych członków społeczeństwa, którzy posiadają w nieproporcjonalnie wysokim stopniu władzę polityczną, traktowaną jako zdolność do kontrolowania systemu rządzenia w państwie (national governing system). W takim ujęciu demokracja to stopień w jakim władza polityczna elit jest zminimalizowana, zaś zmaksymalizowana ta, która nie przynależy elitom ${ }^{14}$. Równocześnie jednak autor zauważa, że definicja ta jest bardzo trudna do przełożenia na definicję operacyjną, gdyż nie dysponujemy uniwersalną, powszechnie akceptowaną i łatwą w użyciu jednostką pomiaru władzy, analogiczną do pieniądza, będącego jednostką pomiaru wartości. Dlatego K. Bollen proponuje by nie dokonywać pomiaru wprost, a poprzez ocenę dwóch wymiarów demokracji politycznej:

1) polityczne prawa (demokratyczne rządy, suwerenność ludu) - odpowiedzialność polityków przed ludem oraz uprawnienie każdego do bezpośredniego lub pośredniego uczestnictwa w rządzeniu, mierzone np. równością głosów, otwartością selekcji kandydatów, uczciwością wyborów itp.;

2) polityczne wolności - wolność słowa, wolność absencji wyborczej, oporu wobec rządu, uczestnictwa, jak i nieuczestniczenia w życiu politycznym itd. ${ }^{15}$

Problemem jednak jest tu brak bezpośredniego, wyraźnego i jednoznacznego związku pomiędzy definicją teoretycznąi operacyjną. Być może sam autor również to dostrzega, albo-

${ }^{14}$ K. A. Bollen, Political democracy: Conceptual and measurement traps, ,Studies in Comparative International Development" 1990, vol. 25, Issue 1, s. 9.

${ }^{15}$ Ibidem, s. 9-10. 
wiem w swoich późniejszych publikacjach odchodzi już od formułowania definicji teoretycznej, uznając po prostu, że demokracja jest tożsama $\mathrm{z}$ zakresem $\mathrm{w}$ jakim $\mathrm{w}$ danym systemie obowiązują polityczne prawa oraz polityczne wolności ${ }^{16}$. Równocześnie zauważa on zbieżność takiego pojmowania demokracji z koncepcją poliarchii Roberta Dahla.

Konstrukcja skali Bollena jest stosunkowo prosta. Do każdego z dwóch wymiarów demokracji przypisane są bowiem zaledwie po trzy wskaźniki:

a) wolności polityczne:

1) wolność prasy,

2) wolność do zrzeszania się w partie polityczne i bycia w opozycji do władzy,

3) zakres restrykcji nakładanych przez władze na jednostki i grupy;

b) prawa polityczne:

1) uczciwość wyborów,

2) pochodzenie szefa egzekutywy z wyboru (pośredniego lub bezpośredniego),

3) pochodzenie z wyboru oraz efektywność narodowego ciała ustawodawczego.

Każdy ze wskaźników podlega ocenie ze strony sędziów kompetentnych, którzy umieszczali wynik danego kraju na kilkustopniowej skali (skala wolności prasy miała 9 stopni, wolności zrzeszania się i opozycji - 4 stopnie, uczciwości wyborów - 4 stopnie itd.). Następnie wyniki były przeliczane proporcjonalnie na skalę od 0 do 100, zaś ewentualne braki danych uzupełniane były poprzez estymację metodą najmniejszych kwadratów. Ostateczna wielkość indeksu mierzącego demokrację jest średnią z wyników wszystkich sześciu wskaźników.

Zaletą skali Bollena jest to, że jej autor przyłożył dużą wagę do oceny jej trafności, rzetelności oraz jednowymiarowości, a także do oszacowania wagi poszczególnych wymiarów. Użył on do tego celu zaawansowanych narzędzi statystycznych, takich jak np. konfirmacyjna analiza czynnikowa ${ }^{17}$. Choć jednak od strony czysto technicznej skala jest przygotowana bardzo skrupulatnie, to pozostawia wiele do życzenia w warstwie teoretycznej i operacjonalizacyjnej. Ponadto wiele informacji dotyczących procesu badawczego pozostaje ukryte przed odbiorcami. Nie wiadomo np. jakie konkretnie kryteria oceny zostały zastosowane w każdym z dość ogólnikowo zarysowanych wskaźników, ilu sędziów kompetentnych dokonywało ocen, jaki był stopień ich zbieżności itd. Gdyby zatem ktoś chciał zastosować skalę Bollena do prowadzenia własnych pomiarów, miałby z tym duże problemy - wydaje się, że skonstruowana została ona jako narzędzie do stworzenia zbioru danych wyłącznie przez jej autora.

\section{Political Regimes Project}

Kolejna propozycja pomiaru demokracji, zorientowana na cele czysto badawcze, jest zawarta w Projekcie Badania Reżimów Politycznych (Political Regimes Project) Marka J. Gasiorowskiego $^{18}$. Nie koncentruje się ona wyłącznie na pomiarze demokratyczności systemu, ale traktuje ją zaledwie jako jeden z możliwych wektorów charakteryzujących reżim politycz-

\footnotetext{
${ }^{16}$ Zob. np. K. A. Bollen, Liberal Democracy: Validity and Method Factors in Cross-National Measures, „American Journal of Political Science" 1993, vol. 37, Issue 4, s. 1208-1209; K. A. Bollen, P. Paxton, Subjective Measures of Liberal Democracy, „Comparative Political Studies” 2000, vol. 33, Issue 1, s. 59-62.

${ }^{17}$ K. A. Bollen, Issues in The Comparative Measurement of Political Democracy, „American Sociological Review" 1980, vol. 45, Issue 3, s. 377-379.

${ }^{18}$ M. J. Gasiorowski, The Political Regimes Project, „Studies in Comparative International Development” 1990, vol. 25, Issue 1; M. J. Gasiorowski, An overview of the political regime change dataset, „Comparative Political Studies" 1996, vol. 29, Issue 4.
} 
ny. Autor przyjmuje bowiem, że można wyróżnić trzy typy idealne reżimu politycznego: reżim demokratyczny, reżim autorytarny oraz reżim totalitarny. Wychodząc od ich definicji teoretycznych, sformułował on 7 wymiarów charakteryzujących reżim polityczny (tab. 1).

Tabela 1

Wymiary reżimów politycznych wg M. Gasiorowskiego.

\begin{tabular}{||l|c|c|c||}
\hline \multicolumn{1}{|c|}{ Wymiar } & Demokracja & Totalitaryzm & Autorytaryzm \\
\hline Wolność organizowania się i wypowiedzi & Tak & Nie & Nie \\
\hline $\begin{array}{l}\text { Obsadzanie urzędów państwowych w drodze wyłaniania } \\
\text { przedstawicieli na zasadzie reprezentacji }\end{array}$ & Tak & Nie \\
\hline $\begin{array}{l}\text { Występowanie instytucji państwa opartych o zasadę repre- } \\
\text { zentatywności }\end{array}$ & Tak & Nie & $?$ \\
\hline Liczba i charakter partii politycznych & Więcej niż 1 & 1 totalitarna & $?$ \\
\hline Istnienie dominującej ideologii totalitarnej & Nie & Tak & Nie \\
\hline Dominacja państwa/partii nad organizacjami społecznymi & Nie & Tak & $?$ \\
\hline Występowanie represji na tle politycznym & Nie & Tak & Tak \\
\hline
\end{tabular}

Źródło: M. J. Gasiorowski, The Political Regimes Project, „Studies in Comparative International Development” 1990, vol. 25, Issue 1, s. 111 .

Pierwsze trzy wymiary odnoszą się bezpośrednio do sformułowanych przez Roberta Dahla wymogów proceduralnych poliarchii ${ }^{19}$, kolejne trzy natomiast zaczerpnięte zostały z charakterystyki reżimów totalitarnych według C. J. Friedricha ${ }^{20}$. Ostatni wymiar został dodany przez samego autora.

Na podstawie wartości innych, mniej istotnych zmiennych, autor wyróżnił też podtypy reżimów politycznych, niespełniające jednak postulatu rozłączności. W przypadku demokracji tymi zmiennymi są: charakter zasady reprezentacji (system prezydencki/parlamentarny oraz wybory większościowe/proporcjonalne), charakter systemu partyjnego (liczba liczących się partii, dystrybucja władzy między partiami, występowanie partii ekstremistycznych) oraz istnienie mechanizmów sprzyjających rozwiązaniom konsocjonalnym. W odniesieniu do reżimu totalitarnego rozstrzygającym jest charakter dominującej ideologii (lewicowa, prawicowa, populistyczna). Z kolei w przypadku reżimów autorytarnych oparto się na koncepcji J. Linza i wyróżniono następujące podtypy: tradycjonalny, wojskowy, biurokratyczny, korporacyjny, „demokracji” rasowej/etnicznej, posttotalitarny, mobilizacyjny, personalistyczny oraz populistyczny ${ }^{21}$.

Ogólnie projekt badania reżimów politycznych M. Gasiorowskiego objął 35 zmiennych, w większości trójwartościowych. Oprócz zmiennych służących do wyróżniania typów i podtypów reżimów politycznych, w zbiorze danych znalazły się również inne, mogące być wykorzystane jako zmienne niezależne bądź zależne w badaniu relacji między reżimem politycznym a innymi ważnymi charakterystykami systemu politycznego, ekonomicznego itd. Baza danych objęła 117 krajów (liczących powyżej miliona mieszkańców) w latach 1946-1988.

${ }^{19}$ R. Dahl, Polyarchy: Participation and Opposition, New Haven 1971, s. 2-3.

${ }^{20}$ C. J. Friedrich, The evolving theory and practice of totalitarian regimes, w: Totalitarianism in Perspective: Three Views, red. C. J. Friedrich, M. Curtis, B. R. Barber, New York 1969.

${ }^{21} \mathrm{~J}$. Linz, Totalitarian and authoritarian regimes, w: Handbook of political science, vol 3: Macropolitical theory, red. F. I. Greenstein, N. W. Polsby, Reading (MA) 1975, s. 252-350. 


\section{The Polity Project}

Polity Project jest jednym z najczęściej wykorzystywanych i przywoływanych w badaniach porównawczych źródeł danych o poziomie demokracji w różnych krajach. Jest to zbiór danych (dataset) obejmujący swoim zasięgiem praktycznie wszystkie większe kraje na świecie na przestrzeni ostatnich dwóch wieków, przygotowywany i ulepszany przez zespół amerykańskich badaczy od ponad $30 \mathrm{lat}^{22}$.

Podstawą teoretyczną projektu był artykuł jednego z jej twórców, T. R. Gurra na temat zmiany i trwałości ustrojów politycznych w XIX i XX wieku ${ }^{23}$, rozbudowany następnie w monografię napisaną wspólnie z Harrym Ecksteinem ${ }^{24}$. Dała ona początek projektowi Polity I, który później był kontynuowany jako Polity II, III i IV. W każdej kolejnej edycji zwiększała się liczba wskaźników opisujących systemy polityczne, a także zasięg czasowy i przestrzenny zbioru danych - w Polity IV mamy już do czynienia z 35 charakterystykami, zaś sam zbiór danych obejmuje 163 kraje w latach 1800-2008.

Cechą charakterystyczną projektu Polity jest to, iż jest w nim mierzona nie tylko demokratyczność systemów, ale również ich autokratyczność - mamy zatem do czynienia z dwoma odrębnymi skalami, które dopiero później zostają w sposób sztuczny połączone we wspólną skalę demokracji-autokracji.

Demokratyczność systemu oceniana jest na podstawie trzech wskaźników:

— rywalizacyjności w uczestnictwie politycznym;

— otwartości i rywalizacyjności w rekrutacji na stanowiska władcze;

— ograniczeń nałożonych na najwyższych urzędników państwowych.

Wskaźnikami autokratyczności są natomiast:

— brak uregulowanych form politycznego współzawodnictwa;

— brak poszanowania wolności obywatelskich i politycznych.

Ocena wysokości poszczególnych wskaźników ma charakter subiektywny i jest przeprowadzana przez samych badaczy - dla każdego kraju przyporządkowują oni odpowiednią wartość liczbową.

Ostatecznie wyniki z obu skal zostają połączone, poprzez odjęcie punktów na skali autokratyczności od sumy punktów na skali demokratyczności, we wspólny indeks demokracji-autokracji. Jest to zabieg czysto matematyczny, sztuczny i arbitralny, tym bardziej, że skale te nie są w poszczególnych wymiarach symetryczne, zaś liczba punktów możliwych do uzyskania w poszczególnych wymiarach jest różna. Autorzy wykazują tu zresztą pewną niekonsekwencję, postulując najpierw osobne i niezależne mierzenie demokratyczności oraz au-

\footnotetext{
${ }^{22}$ Obszerna charakterystyka projektu Polity znalazła się m.in. w artykułach: T. R. Gurr, K. Jaggers, W. H. Moore, The Transformation of the Western State: The Growth of Democracy, Autocracy, and State Power Since 1800, ,Studies in Comparative International Development" 1990, vol. 25, Issue 1, s. 73-108; S. McLaughlin, S. Gates, H. Hegre, R. Gissinger, N. P. Gleditsch, Timing the Changes in Political Structures: A New Polity Database, „Journal of Conflict Resolution" 1998, vol. 42, no. 2, s. 231-242; K. Jaggers, T. R. Gurr, Tracking Democracy's Third Wave with the Polity III Data, ,Journal of Peace Research” 1995, vol. 32, Issue 4, s. 469-482. Szczegółowy opis metodologii Polity IV zawiera przygotowany przez uczestników projektu manual: M. G. Marshall, K. Jaggers, Polity IV Project: Political Regime Characteristics and Transitions, 1800-2007. Data Users' Manual, http://www.systemicpeace.org/inscr/ p4manualv2007.pdf [10.01.2010]. Krótkie przedstawienie podstawowych celów i założeń Polity IV oraz najnowsze analizy wykonane w jego ramach dostępne są na stronie domowej projektu: http://www.systemicpeace.org/polity/polity4.htm [10.01.2010].

${ }^{23}$ T. R. Gurr, Persistence and Change in Political Systems, 1800-1971, „American Political Science Review” 1974, vol. 68, Issue 4, s. 1482-1504.

${ }^{24}$ H. Eckstein, T. R. Gurr, Patterns of Authority: A Structural Basis for Political Inquiry, New York 1975.
} 
tokratyczności systemów, a następnie integrując, wyniki tych pomiarów w jeden syntetyczny indeks.

Zaletami Polity są przede wszystkim:

— szeroki zakres czasowy i przestrzenny, jaki obejmuje zbiór danych;

- łatwa dostępność danych - wszystkie są dostępne do pobrania na stronie internetowej projektu, zapisane w formatach, które mogą być łatwo zaimportowane przez popularne pakiety statystyczne,

— fakt, że jest to projekt prowadzony już od kilkudziesięciu lat - jego autorzy dysponują więc dużym doświadczeniem, zaś sam zbiór danych jest nieustannie poprawiany i korygowany, jak również uzupełniany na bieżąco o dane z kolejnych lat.

W projekcie widoczne sa jednak pewne niedostatki natury metodologicznej i teoretycznej. Uzasadnienie operacjonalizacji i doboru wskaźników wydaje się niewystarczające, wagi poszczególnych wskaźników są nierówne (bez wyrażonego explicite uzasadnienia), zaś przyznawane punkty są oparte na czysto subiektywnych ocenach, opartych na niezbyt precyzyjnie zarysowanych kryteriach. Ponadto autorzy, przyznając że ważnym wymiarem demokracji są prawa człowieka i gwarancje swobód obywatelskich, nie włączają go do modelu badawczego, motywując to wysoką zmiennością historyczną poziomu ich realizacji. W ten sposób świadomie pomijają jeden z najważniejszych i najsilniej różnicujących systemy polityczne elementów oceny jakości demokracji. Badacz chcący zastosować dane z projektu Polity do własnych analiz winien być świadomy tych ograniczeń i mankamentów. Tym niemniej dane te są jednymi z najczęściej używanych w politologicznych badaniach ilościowych z zakresu komparatystyki.

\section{Indeks demokratyzacji Vanhanena}

Kolejną skalą jest tzw. Indeks Demokratyzacji (ID), opracowany przez fińskiego badacza Tatu Vanhanena ${ }^{25}$. Podstawą indeksu jest rozróżnienie dwóch wymiarów poliarchii (rywalizacji i partycypacji), podobne do dokonanego w klasycznej monografii R. Dahla ${ }^{26}$. Ciekawostką może być jednak fakt, że pierwsze wersje indeksu powstały zanim jeszcze jego twórca zapoznał się z tą pozycją, zaś dopiero później dostrzegł zbieżność pomiędzy własnym narzędziem a koncepcją stworzoną przez amerykańskiego teoretyka demokracji i uznał ją właśnie za podstawę teoretyczną dokonywanego pomiaru.

Sam indeks jest zatem bardzo prosty, co ma stanowić jego walor. T. Vanhanen uważa bowiem, że pozostałe indeksy są zbyt skomplikowane, opierają się na zbyt dużej ilości wskaźników oraz zbytnio polegają na subiektywnych ocenach badaczy. ID opiera się na zaledwie dwóch jednowymiarowych zmiennych, traktowanych jako wskaźniki stopnia rywalizacji i stopnia partycypacji.

25 T. Vanhanen, A New Dataset for Measuring Democracy, 1810-1998, ,Journal of Peace Research” 2000, vol. 37 , Issue 2, s. 251-265; T. Vanhanen, Polyarchy Dataset Manuscript, http://www.prio.no/CSCW/Datasets/Governance/Vanhanens-index-of-democracy/Polyarchy-Dataset-Manuscript/ [17.01.2010]. Charakterystyka zbioru danych i podstaw metodologicznych skali przedstawiona jest również w monografiach autorstwa i pod redakcją tego badacza, w których wykorzystuje on te dane do analiz porównawczych, np.: T. Vanhanen, Democratization. A comparative analysis of 170 countries, London-New York 2003, s. 48-78; Strategies of Democratization, red. T. Vanhanen, Washington-London 1992, s. 22 i n.; Democratization in Eastern Europe. Domestic and international perspectives, red. G. Pridham, T. Vanhanen, London-New York 2003, s. 85 i n.

${ }^{26}$ R. Dahl, Polyarchy: Participation and Opposition, op. cit. 
Pierwszą ze zmiennych jest tzw. udział głosów oddanych na mniejsze partie (smaller parties' share of votes), czyli łączny odsetek głosów wyborczych jakie uzyskały w ostatnich wyborach wszystkie partie poza tą, która tych głosów uzyskała najwięcej:

$$
C=100 \%-g
$$

gdzie: $C$ - wskaźnik rywalizacji;

$g$ - wynik wyborczy partii wygrywającej wybory (w \%).

Ten wskaźnik opiera się na założeniu, iż to partie polityczne reprezentują najważniejsze ośrodki władzy politycznej w społeczeństwie, a więc im więcej głosów osiągają małe partie, tym szersza jest dystrybucja władzy w społeczeństwie. Jest on prosty w swojej konstrukcji, jednak w praktycznym zastosowaniu istnieje przynajmniej kilka kwestii nastręczających trudności. Wymogły one na autorze indeksu wprowadzenie dodatkowych założeń. Przykładowo, wprowadzono arbitralnie ustaloną na poziomie 30\% maksymalną wartość wskaźnika rywalizacji dla krajów z ordynacjami większościowymi. W ten sposób wskaźnik traci jednak na swojej przejrzystości i staje się bardziej uzależniony od subiektywnych ocen badacza.

Drugą zmienną jest poziom partycypacji, którego wskaźnikiem jest wysokość frekwencji wyborczej. W przeciwieństwie do zazwyczaj przyjmowanego rozumienia frekwencji, autor nie traktuje jej jako stosunek liczby oddanych głosów do liczby uprawnionych do głosowania, ale do całej ludności kraju:

$$
P=\frac{v}{l} \times 100 \%
$$

gdzie: $P$ - wskaźnik partycypacji;

$v$ - liczba oddanych głosów wyborczych;

$l$ - liczba wszystkich mieszkańców kraju.

Przyjęcie za podstawę obliczenia całej populacji zostało spowodowane łatwiejszą dostępnością danych. Powoduje ono jednak ryzyko odkształceń spowodowanych odmienną strukturą demograficzną różnych krajów, szacowanych nawet na $10-15 \%$.

Każda z dwóch zmiennych została przedstawiona w postaci procentowej (od 0 do 100\%). Indeks Demokratyzacji jest ich iloczynem, wyrażonym w postaci procentowej:

$$
I D=C \times P \times 100 \%
$$

gdzie: $I D$ - Indeks Demokratyzacji;

$C$ - wysokość wskaźnika rywalizacji;

$P$ - wysokość wskaźnika partycypacji.

Teoretycznie wysokość $I D$ może wynosić od 0 do 100\%, jednak w praktyce jego wartości zawierają się w przedziale od 0 do niecałych $50 \%$. Zdaniem T. Vanhanena za systemy demokratyczne należałoby uznać te, które spełniają równocześnie trzy warunki:

— wartość wskaźnika rywalizacji wynosi co najmniej 30\%;

— wartość wskaźnika partycypacji wynosi co najmniej 10\% (w niektórych pracach było to $15 \%)$;

— wysokość ID musi być powyżej 5\%.

Koncepcja Indeksu Demokratyzacji T. Vanhanena jest przykładem skrajnie kwantytatywnego podejścia do problematyki pomiaru demokracji. Autor usiłuje opierać całą koncepcję 
pomiaru na tym co bezpośrednio obserwowalne i mierzalne. Można też powiedzieć, że priorytetem jest tu ekonomiczność procesu badawczego, a więc osiągnięcie zadowalających wyników przy jak najmniejszym nakładzie środków. I ten cel w zasadzie został osiągnięty - korelacja z rezultatami uzyskanymi przy zastosowaniu innych skal (np. Freedom House) okazała się dość wysoka.

Można jednak poddawać w wątpliwość teoretyczne uzasadnienie skali, pomijającej wiele istotnych wymiarów demokracji. Indeks Demokratyzacji opiera się jedynie na zmiennych związanych z wyborami i dystrybucją głosów wyborczych, a więc redukuje złożoną charakterystykę systemów politycznych do samego procesu wyborczego. Niewystarczająco jest on też wyczulony na kwestię istotności wyborów, co powinno skłonić badaczy chcących posługiwać się tym narzędziem do szczególnej ostrożności.

\section{Skala poliarchii Coppedge'a i Reinicke}

Ostatnia z omawianych skal została stworzona przez dwóch amerykańskich badaczy: Michaela Coppedge'a oraz Wolfganga H. Reinicke ${ }^{27}$. Autorzy wychodzą od stwierdzenia, iż kategoria „poliarchii” praktycznie zastąpiła kategorię „demokracji” w badaniach politologicznych. Dlatego, dla zachowania przejrzystości językowej oraz klarowności odniesień teoretycznych, autorzy skali nazywają ją skalą poliarchii.

Poliarchia, w przeciwieństwie do demokracji, jest zdaniem M. Coppedge'a i W. Reinicke stopniowalna i mierzalna. Dotyczy ona tylko podstawowych instytucjonalnych wymogów demokracji - a więc tych, które są najłatwiejsze do zaobserwowania i zmierzenia. Są one wyrazem dwóch wymiarów składających się, według koncepcji Roberta Dahla, na poliarchię: opozycji i partycypacji (inaczej mówiąc, kontestacji i inkluzji) ${ }^{28}$.

Skala poliarchii Coppedge'a i Reinicke opiera się na czterech zmiennych, których wartości ustalano na podstawie subiektywnych ocen badaczy:

1) wolne i uczciwe wybory (FAIRELT);

2) wolność zrzeszania się (FREORG);

3) wolność wypowiedzi (FREXT);

4) dostępność alternatywnych źródeł informacji (ALTINF).

Początkowo w indeksie planowano umieszczenie także zmiennej SUFF, której wartość wyznaczona była przez zakres podmiotowy prawa do głosu (tzn. jaka część społeczeństwa jest uprawniona do głosowania w wyborach). W trakcie analizy danych okazało się jednak, że włączenie tej zmiennej niewiele by wnosiło, bowiem jedynie w przypadku RPA i Samoa Zachodniego wysokiemu wynikowi w pozostałych wymiarach nie towarzyszył wysoki poziom inkluzyjności. Zdecydowano się zatem usunąć zmienną SUFF z analizy. W ten sposób stworzono skalę jednowymiarową - spośród dwóch wymiarów poliarchii według R. Dahla, mierzy ona wymiar kontestacji (opozycji), utożsamiając go z poliarchią w ogóle.

Dzięki jednowymiarowości skali, można było, zbudować ją na zasadzie skalogramu Guttmana $^{29}$. Dzięki temu m.in. uniknięto problemu przypisania wag poszczególnym wskaźnikom

\footnotetext{
${ }^{27}$ M. Coppedge, W. H. Reinicke, Measuring Polyarchy, „Studies in Comparative International Development” 1990, vol. 25, Issue 1, s. 51-72. Dane pochodzące ze zbioru dostępne są na stronie: http://www.nd.edu/ mcoppedg/crd/datacrd.htm [15.02.2010].

${ }^{28}$ R. Dahl, Polyarchy: Participation and Opposition, op. cit.

${ }^{29}$ Por. S. A. Stouffer, Skalogram Guttmana, w: Metody badań socjologicznych, red. S. Nowak, Warszawa 1965, s. 304-313.
} 
oraz uzyskano skalę łatwą i przejrzystą w interpretacji. Trzeba przyznać, że jest to bardzo zgrabny zabieg metodologiczny, przynoszący wiele korzyści, tym bardziej że Autorom udało się to uczynić, zachowując wysoki stopień trafności fasadowej skali oraz jej rzetelności, przy uzyskaniu wysokiego współczynnika odtwarzalności skalogramu (powyżej 0,9).

Wadą skali poliarchii jest natomiast to, że bardzo wiele państw zdobywa na niej najwyższy możliwy wynik, a zatem nie jest ona w stanie uchwycić subtelności i różnic między systemami demokratycznymi. Jest to konsekwencją faktu, iż koncepcja poliarchii odnosi się jedynie do minimalnych wymogów proceduralnych demokracji. Pomiar poliarchiczności nie pozwala na dokonywanie szczegółowej, subtelnej i zniuansowanej oceny jakości demokracji. Autorzy skali uznali jednak, że ważniejszym jest dla nich zachowanie jednowymiarowości skali. Można zrozumieć takie stanowisko, badaczom udało się bowiem stworzyć model pomiaru bardzo „elegancki” zarówno pod względem teoretycznym, jak i metodologicznym. Wydaje się jednak, że to rozwiązanie pozostawia mimo wszystko pewien niedosyt.

\section{Zakończenie}

W artykule przedstawione zostały zaledwie niektóre propozycje pomiaru demokracji, jakie funkcjonują w zachodniej politologii. Dobór został przeprowadzony w sposób subiektywny, jednak starano się przedstawić te koncepcje, których stworzenie miało największy oddźwięk w środowisku politologów porównawczych. Przejawia się on zarówno w postaci szerokiego wykorzystania skali w badaniach empirycznych i analizach porównawczych, jak i dużej liczby głosów polemicznych czy krytycznych. Nie jest pewnie kwestią przypadku, że najszerzej używane, przywoływane i komentowane sposoby pomiaru demokracji są zazwyczaj koncepcjami dopracowanymi, o wysokich walorach metodologicznych i poznawczych. I choć nadal są one z pewnością dalece niedoskonałe, to należy docenić wysiłki ich twórców nakierowane na ich ulepszanie pod względem teoretycznym i metodologicznym. Ostatecznie są to, nawet mimo pewnych ich mankamentów, narzędzia nieodzowne przy rozstrzyganiu niektórych kluczowych dla politologii porównawczej problemów badawczych, a z pewnością godne tego by wiedzieć o ich istnieniu i możliwościach zastosowania.

\section{Bibliografia}

Barman D. Ch., Rahman M. G., Siddiqui T., State of Democracy in Bangladesh, Momin Offset Press, Dhaka 2000.

Barro R. J., Determinants of Democracy, „Journal of Political Economy” 1999, vol. 107, Issue 6 Part 2.

Beetham D., Bracking S., Kearton I., Vittal N., Weir S., The State of Democracy. Democracy Assessments in Eight Nations Around the World, Kluwer Law International, Hague 2002.

Beetham D., Carvalho E., Landman T., Weir S., Assessing the Quality of Democracy. A Practical Guide, Stockholm 2008.

Bollen K. A., Issues in The Comparative Measurement of Political Democracy, „American Sociological Review" 1980, vol. 45, Issue 3.

Bollen K. A., Liberal Democracy: Validity and Method Factors in Cross-National Measures, „American Journal of Political Science" 1993, vol. 37, Issue 4.

Bollen K. A., P. Paxton, Subjective Measures of Liberal Democracy, „Comparative Political Studies” 2000, vol. 33, Issue 1.

Bollen K. A., Political democracy: Conceptual and measurement traps, „Studies in Comparative International Development" 1990, vol. 25, Issue 1. 
Coppedge M., Reinicke W. H., Measuring Polyarchy, „Studies in Comparative International Development” 1990, vol. 25, Issue 1.

Dahl R., Polyarchy: Participation and Opposition, New Haven 1971.

Dizdarević S., et al., Democracy Assessment in Bosnia and Herzegovina, Open Society Fund Bosnia and Herzegovina, Sarajevo 2006.

Eckstein H., Gurr T. R., Patterns of Authority: A Structural Basis for Political Inquiry, New York 1975.

Friedrich C. J., The evolving theory and practice of totalitarian regimes, w: Totalitarianism in Perspective: Three Views, red. C. J. Friedrich, M. Curtis, B. R. Barber, New York 1969.

Gasiorowski M. J., An overview of the political regime change dataset, „Comparative Political Studies” 1996, vol. 29, Issue 4.

Gasiorowski M. J., The Political Regimes Project, „Studies in Comparative International Development” 1990, vol. 25, Issue 1.

Gastil R. D., The Comparative Survey of Freedom: Experiences and Suggestions, „Studies in Comparative International Development" 1990, vol. 25, Issue 1.

Gurr T. R., Jaggers K., Moore W. H., The Transformation of the Western State: The Growth of Democracy, Autocracy, and State Power Since 1800, „Studies in Comparative International Development” 1990, vol. 25, Issue 1.

Gurr T. R., Persistence and Change in Political Systems, 1800-1971, „American Political Science Review” 1974, vol. 68, Issue 4.

Gutman A., Demokracja, w: Przewodnik po współczesnej filozofii politycznej, red. R. E. Goodin, F. Pettit, Warszawa 2002.

Hughers I., Clancy P., Harris C., Beetham D., Power to the People? Assessing Democracy in Ireland, New Island Books, Dublin 2007.

Huntington S. P., The Modest Meaning of Democracy, w: Democracy in the Americas: Stopping the Pendulum, red. R. A. Pastor, New York-London 1989.

Huntington S. P., Trzecia fala demokratyzacji, Warszawa 1995.

Inglehart R., Welzel Ch., Modernization, cultural change, and democracy: the human development sequence, New York 2005.

Jaggers K., Gurr T. R., Tracking Democracy's Third Wave with the Polity III Data, „Journal of Peace Research" 1995, vol. 32, Issue 4.

Kekic L., The Economist Intelligence Unit's index of democracy, „The Economist” 2006, nr specjalny: The World in 2007.

Landman T., Assessing the Quality of Democracy. An Overview of the International IDEA Framework, Stockholm 2008.

Linz J., Totalitarian and authoritarian regimes, w: Handbook of political science. Vol 3.: Macropolitical theory, red. F. I. Greenstein, N. W. Polsby, Reading (MA) 1975.

Marshall M. G., Jaggers K., Polity IV Project: Political Regime Characteristics and Transitions, 1800-2007. Data Users' Manual, http://www.systemicpeace.org/inscr/p4manualv2007.pdf [10.01.2010].

McLaughlin S., Gates S., Hegre H., Gissinger R., Gleditsch N. P., Timing the Changes in Political Structures: A New Polity Database, „Journal of Conflict Resolution” 1998, vol. 42, no. 2.

Mouffe Ch., Paradoks demokracji, Wrocław 2005.

O’Loughlin J., Global Democratization: Measuring and Explaining the Diffusion of Democracy, w: Spaces of Democracy. Geographical Perspectives on Citizenship, Participation and Representation, red. C. Barnett, M. Low, London-Thousand Oaks-New Delhi 2004.

Pridham G., Vanhanen T. (red.), Democratization in Eastern Europe. Domestic and international perspectives, London-New York 2003.

Rozenvalds J., Mežaraups I. (red.), How Demorcatic is Latvia. Audit of Democracy, Latvijas Universitāte Akadēmiskais apgāds, Riga 2005.

Schumpeter J. A., Kapitalizm, socjalizm, demokracja, Warszawa 2009.

Shapiro I., Stan teorii demokracji, Warszawa 2006.

Stouffer S. A., Skalogram Guttmana, w: Metody badań socjologicznych, red. S. Nowak, Warszawa 1965.

Szewczak W., Jak zmierzyć demokrację? Teoretyczne i metodologiczne podstawy budowy skal demokracji politycznej w politologii porównawczej, „Przegląd Politologiczny” 2010, nr 4. 
The Economist Intelligence Unit's Index of Democracy 2008, „The Economist” 2008, nr specjalny: The World in 2009 .

Tilly Ch., Demokracja, Warszawa 2008.

Vanhanen T. (red.), Strategies of Democratization, Washington-London 1992.

Vanhanen T., A New Dataset for Measuring Democracy, 1810-1998, „Journal of Peace Research” 2000, vol. 37 , Issue 2 .

Vanhanen T., Democratization. A comparative analysis of 170 countries, London-New York 2003.

Vanhanen T., Polyarchy Dataset Manuscript, document elektroniczny na stronie: http://www.prio.no/CSCW/Datasets/Governance/Vanhanens-index-of-democracy/Polyarchy-Dataset-Manuscript/ [17.01.2010].

Wilford R., Wilson R., Claussen K., Power to the People? Assessing Democracy in Northern Ireland, New Island Books, Dublin 2007.

http://www.freedomhouse.org [20.03.2010].

http://www.nd.edu/ mcoppedg/crd/datacrd.htm [15.02.2010].

http://www.systemicpeace.org/polity/polity4.htm [10.01.2010].

\section{Summary}

The author reviews and characterizes the most important scales for measuring the democracy of political systems, applied in Western, mainly Anglo-Saxon, comparative political science. He refers to his article published in a back issue of Przeglad Polityczny, where the fundamental theoretical and methodological issues of democracy measuring were presented, and tries to indicate how these issues are dealt with by various researchers whose scales and data bases are most common and most frequently referred to in research into political comparative studies. The paper describes S. Huntington's analyses, the Freedom House scale, the IDEA assessment of the quality of democracy, the EIU democracy index, Bollen's scale, the Political Regimes Project, the Polity Project, T. Vanhanen's democracy index and the scale of polyarchy by Coppedge and Reinicke.

As the author analyzes one scale and database after another, he tries to identify their strengths and weaknesses, determine the most characteristic properties of each proposal, and assess their applicability in comparative analyses, pointing to their potential benefits and the threats of using them. In conclusion, he recommends caution in the selection of a scale to become a foundation for potential analyses, while he acknowledges that this theoretical and methodological tool is highly useful. 
